\title{
Transitions revisited: The end of the Portuguese colonial empire in Luso-African cinema (1974-2014)
}

The 1974 Carnation Revolution set one of the greatest upheavals of LusoAfrican contemporary history in motion. It brought about the end of almost half a century of dictatorship and 500 years of colonial rule, which had become anachronistic and had been opposed by various independence movements since the 1950s. For Angola, Cape Verde, East Timor, Guinea-Bissau, Mozambique and São Tomé and Príncipe, 1974 meant the end of a long fight for independence, but also sparked civil war, massacres, displacement and migration. The process of coming to terms with these events is still incomplete. For Portugal, it meant coping with the loss of its empire, being confined to its European territory and accepting its own postcolonial condition. 
This special issue of the Journal of African Cinemas comprises case studies on cinematic representations of the 1974 upheaval and the end of the Portuguese colonial empire, aiming to stimulate renewed reflection on the dynamics of multi-perspective interpretations of the independence processes in Africa, civil wars and displacement processes in the aftermath of the Carnation Revolution. Over the past 40 years, Luso-African cinema has been one of the most powerful means of addressing the radical societal changes brought about by the political rupture of 1974 . These films do not generate historical evidence, but are rather attempts to bring historical knowledge and audio-visual culture together to dynamically enact or produce 'visions of the past' (Rosenstone 1998). Fictional dramas and documentaries use the power of moving images to revisit the past to make sense of the present (Thackway 2003; Cham 2004). Cinematic techniques and practices such as the integration of archival material, eyewitness accounts and voice-over (Stock 2014) are used to stress critical and challenging interpretations of the decolonization process in Luso-African cinema.

\section{REVISITING DECOLONIZATION 40 YEARS AFTER}

The twenty-first-century episteme of memory - or even 'hypertrophy of memory', as Andreas Huyssen put it (2003: 3) - has facilitated a long overdue widespread debate on the process of decolonization affecting the Portuguesespeaking African states and Portugal. Whereas engaging with the past of 48 years of dictatorship in Portugal started to gain momentum in a major way around the turn of the millennium (Medeiros 2000; Loff 2010: 99; Buettner 2016: 210), there has been more resistance to assessing the decolonization process and its long-lasting consequences - the spectre of collective trauma in all countries involved still being too powerful and the memories still too contested. But even though they do not figure as prominently in the contemporary memory boom as the dictatorship, the colonial past, decolonization and its consequences have been addressed both in academic discourse and in cultural productions in Angola, Cape Verde, Guinea-Bissau, Mozambique and in Portugal, ranging from scientific publications and conferences to literature and film, exhibitions and commemorations (Arenas 2011; Ferreira 2012; Ribeiro et al. 2012; Vieira 2015; Piçarra et al. 2016; Peralta et al. 2017).

For Portugal, the Carnation Revolution on 25 April 1974 brought about the end of a long dictatorship and a complex process of democratization. At the same time, however, it also resulted in the end of colonial rule, with all the associated implications: the negotiation of freedom and independence with the five former colonies in Africa and with East Timor, a negotiation that was highly contested in Portugal and even triggered a state crisis, with the president of the Republic himself resigning due to dissent over unconditional decolonization. Having to absorb half a million returnees from Africa and a huge number of African citizens fleeing from civil war and persecution meant dealing with the challenges of decolonization during a sensitive period of democratization, economic crisis and social turmoil. Taking this context into account, it is hardly surprising that a collective silence set in with the country's gradual democratic consolidation and the rapid integration of the Portuguese returnees as the topic of decolonization tended to be avoided in political debates (Lubkemann 2005). Forty years later, this silence has definitely been broken, but addressing Portugal's past of colonialism, colonial war and decolonization still remains a contested issue. On the one hand, there are critical 
approaches, seeking to address the war from different perspectives. Margarida Cardoso's Natal 71 ('Christmas 71') (1999) was one of the first cinematographic productions offering a distanced and critical gaze on the colonial war and the Estado Novo colonial propaganda. Some years later, Joaquim Furtado's Guerra Colonial/de Libertação/do Ultramar ('Colonial/liberation/overseas war') (2007) confronted TV audiences with a differentiated interpretation of the colonial war, showing that the thirteen years of war were not only a Portuguese trauma but also a legitimate struggle for the right to self-determination of the peoples in Africa, a struggle for the end of colonial rule and, consequently, a struggle for human rights. This debate is reflected in a similar, albeit more experimental manner in Susana de Sousa Dias' film 48 (2009), in which former political prisoners from Mozambique and Portugal share their memories of torture while being detained by the secret police PIDE/DGS. Critical documentaries such as Diana Andringa's and Flora Gomes' As Duas Faces da Guerra ('Both sides of the war') (2007) also give evidence of the current search for a multi-layered view of the past.

On the other hand, however, the colonial past has also been addressed in a nostalgic and even demanding way in past decades. Portuguese libraries attest the popularity of former settlers' memoirs of their lives in Africa, which were abruptly destroyed in the aftermath of the '74 Revolution. The topic of the so-called retornados, the Portuguese returnees from Africa, is one the most visible phenomena in Portuguese popular culture today. Literary and journalistic books, TV series and films render visible the social group of the Portuguese settlers, who saw their lives - especially in Angola and Mozambique - threatened by the course of the independence processes and were forced to flee to Portugal during the revolutionary period, where they were often received with hostility (Pinheiro 2015: 179-80; Peralta et al. 2017). Cultural products on the retornados are far more than bucolic accounts of the lost paradise of colonial Africa; rather, they function as a vehicle for a political and moral claim of recognition of their place in history as the victims of what is conceived of as a precipitated decolonization.

However, stressing the current momentum of revisiting the past should not distract from the fact that there have been critical approaches to the decolonization process ever since its beginnings. Here again, cinematic productions together with literature - have played a pivotal role in deconstructing the narratives of the Portuguese colonial empire that had dominated the decades of dictatorship. Contesting official propagandistic productions that ignored and played down practices of forced labour, economic exploitation, poverty and racialized social relations, some films of the 1960s and the 1970s engaged in the development of a critical vision of the experiences in the Portuguese empire. These included Catembe: 7 Dias em Lourenço Marques ('Catembe: 7 Days in Lourenço Marques') (Almeida, 1964) or Deixem-me ao menos subir às palmeiras ('Let me at least climb up the palm trees') (Barbosa, 1972), both produced in Mozambique and forbidden after attracting the censorship's attention (Convents 2011; Piçarra and António 2013a, 2013b). António-Pedro Vasconcelos' Adeus, até ao meu regresso ('Goodbye until I am back') (1974) traced the traumatic effects of the colonial wars in veterans all over Portugal, already alluding to the controversial discussions about decolonization in 1974. After the revolution, Rui Simões' Deus Pátria Autoridade ('God fatherland authority') (1976) presented an anticolonial argument informed by anti-imperial and Cold War logic. When the revolutionary euphoria had faded away and the turmoil of the PREC had ended, films such as Bom Povo Português ('Good Portuguese people') (Simões, 1980), Gestos e 
Fragmentos ('Gestures and fragments') (Seixas Santos, 1980) and Acto dos Feitos da Guiné ('Act of the deeds in Guinea') (Matos Silva, 1980) heralded a critical view of the Estado Novo and its colonial rule.

In Angola, Mozambique and the other former 'overseas provinces', as the Estado Novo had called them since 1951, the consequences of colonialism and decolonization were further-reaching and more multifaceted (Chabal 2002; Cahen 2012). From the 1960s onwards, several movements were engaged in an armed struggle against the Estado Novo and its colonial rule in the Portuguese colonies in Africa in a protracted guerrilla war that lasted for thirteen years. The coup d'état in Lisbon in 1974 paved the way for the end of the armed conflict and the beginning of decolonization. However, independence was far from an 'easy victory' (Minter et al. 2008). Mozambique was surrounded by white minority regimes that were hostile to the FRELIMO's socialist regime. The situation collapsed soon after independence. There followed a military conflict involving Rhodesia and South Africa. During this process, the RENAMO emerged as a political and military force opposing the FRELIMO - a situation that eventually erupted into civil war (Seibert 2003; Dinerman 2006). In Angola, the MPLA was handed power in 1975 but fought against the UNITA and the FNLA, a civil war that lasted until the 2000s. Guinea-Bissau's political situation was not stable either. The country's postcolonial history has been characterized by different rebellions, military coups and internal conflicts. These conflicts and wars affected the civil population, causing violence, displacement and trauma. Furthermore, most of the newly independent states were ruled by one-party systems emerging from the liberation movements and pushing through their often authoritarian modernization projects, even using violence against their political opponents (Pawson 2014). 1989 brought about the end of the Cold War and once more led to radical socio-political change. This had an impact on the situation in the Portuguese-speaking African countries, with Marxist one-party rule losing international support and more or less stable democratization processes taking place. However, many of these countries' problems remain far from resolved today. Both the MPLA and the FRELIMO still remain in power and guard their 'liberation scripts' (Israel 2013), for the history of the independence struggle to a certain extent serves to legitimize their current political power (Melber 2009; Coelho 2013; Pearce 2015). This also holds true for the relationship of these countries with Portugal, which still shows neo-colonial bias.

The developments described had manifold repercussions for how decolonization was perceived in these countries and for how moving images were or could be produced. In Angola, Guinea-Bissau and Mozambique, films and newsreels hailing independence celebrations and propagating the construction of the new states were created. Like nationalist historiography that stressed anticolonial resistance and unity against colonial rule, cinema became an important stage where visions of the nation-building process could be constructed. Collaborating with filmmakers from Europe, Scandinavia, the United States and Canada, the FRELIMO and the MPLA created moving images about the liberated zones and their progress in fighting the colonial power (Cham 2004; Eshun and Gray 2011: 8). After 1974, film productions tended to integrate the anticolonial struggle into the national narratives. One of the most prominent figures in this context was Robert van Lierop, who directed A Luta Continua ('The struggle continues') (1972) and O Povo Organizado ('The people organized') (1976). In Angola, a similar process took 
place with cinematographic works by Sarah Maldoror, António Ole and Ruy Duarte de Carvalho (Piçarra and António 2013a, 2013b).

These films were produced with the support of newly founded national film institutes, of which the Instituto Nacional de Cinema in Mozambique's capital Maputo was one of the most important. The claims of the liberation cinema' (Andrade-Watkins 1995) thus culminated in the cinematic celebration of the independence of Angola and Mozambique in 1975. In this context of stabilizing power after independence, representations of strong and charismatic leaders and a united people became pivotal in meeting the demands of nation building. In this political framework, the independence movements (now political parties) often pursued a rather conventional approach in film production to ensure that the new political message reached the majority of the (rural and illiterate) population.

Experimental productions aiming to create alternative images about the new states and the struggle against colonialism, or those that aimed to involve the rural population in film production were often not welcomed. Attempts to decolonize conventional cinematographic registers turned out to be difficult in post-independent Angola and Mozambique, as projects such as 25 (Martinez Corrêa and Lucas, 1976) demonstrate (Gray 2012). As a result, projects by Jean Rouch, Jean-Luc Godard, Ruy Guerra and other filmmakers often resulted in conflict with the authorities and their conservative cultural policies (Fairfax 2010). The quarrel about Guerra's Mueda, Memória e Massacre ('Mueda, memory and massacre') (Guerra, 1979/1980) is but one striking example of the conflict between a cinema searching for new horizons and the FRELIMO's rather conservative cultural project. Moreover, as civil wars became more aggravated, means for producing moving images grew increasingly scarce.

With the caesura of 1989, there was also a change in cinematic productions. Private companies emerged, pursuing new approaches to the past (Convents 2011; Fendler 2014: 247). In this context, we can observe how memories of colonialism and civil war often became intertwined as the confrontation with the still very present violent legacy of civil war sometimes triggered nostalgia for colonial times, allowing racism and oppression to fade into the background. Furthermore, the political parties in power in contemporary Angola and Mozambique often hold on to their version of a national liberation war to legitimate their rule and downplay their weaknesses and failures (Melber 2009). Against this background, it is not easy for films to openly engage in a critical discussion of the past. However, there have been important projects that have attempted to intervene in this field and bring up new perspectives. Flora Gomes' Udju Azul di Yonta (The Blue Eyes of Yonta) (1992) Zézé Gamboa's O Herói (The Hero) (2004), Maria João Ganga's Na Cidade Vazia (Hollow City) (2004) and Licínio de Azevedo's Virgem Margarida (Virgin Margarida) (2012) and Comboio de Sal e Açúcar (The Train of Salt and Sugar) (2017) approach the recent past in an original and provocative manner. Licínio de Azevedo's documentary films also reflect and articulate new images of the recent Mozambican past, of which he found traces in the Grande Hotel in Beira or at the Ilha de Moçambique (Arenas 2011). We might also consider Isabel de Noronha's Ngwenya, o Crocodilo ('Ngwenya, the crocodile') (2007) about Malangatana and his trajectory as painter and former political prisoner of the secret police PIDE/ DGS in Mozambique. Furthermore, in the documentary field, one could refer to projects such as Independência ('Independence') (Bastos, 2015) or Caminhos da Paz ('Paths of peace') (Carvalho, 2012). These productions perceive postcolonial histories as multi-layered, contributing to a critical vision of the colonial 
or liberation war and therefore reflecting the multiple memories of a shared history. Consequently, it has taken some decades for cinema and documentary films to critically approach the postcolonial histories of their countries. But even though these productions remain marginal, their cultural expression demonstrates the will and creative approaches that African filmmakers have developed to frame the past in a way that makes it possible to reflect upon complex postcolonial entanglements and address contemporary audiences.

As this overview indicates, there is a host of cinematographic productions dedicated to the discussion of the armed struggle for independence, the colonial war and colonial images themselves. The case studies in this special issue aim to explore how the revolution and radical societal changes were translated into moving images. We take as a premise that these films hint at contemporary discourses on the past (Bickford-Smith and Mendelsohn 2007). By taking such a stance, this special issue aims to expand the work of film historians such as Andrade-Watkins (1995), Arenas (2011, 2015), Convents (2011), Meleiro (2012), Ferreira (2012), Piçarra and António (2013a, 2013b, 2015) and Fendler (2014), which provides essential information on the film history of Angola, Cape Verde, Guinea-Bissau, Mozambique and Portugal. This issue deepens some of these trends and this knowledge by concentrating on different case studies.

\section{CONTRIBUTIONS}

The contributions in this issue deal with cinematographic productions from or about Angola, Cape Verde, Guinea-Bissau, Mozambique and Portugal from multifaceted perspectives. Whereas the African cinemas contributed to the nation-building processes of the new independent states, searching for a narrative of collective identity beyond colonialism, Portuguese cinema was concerned with coming to terms with the loss of the empire and with reformulating a new identity within the context of European integration.

The opening article by Carolin Overhoff Ferreira offers a comprehensive comparative reflection on forty years of Luso-African film productions, reflecting this issue's purpose of revisiting those productions and their representations of the end of the Portuguese empire. Tackling both classical and more current concepts of postcolonial theory, Ferreira traces the evolution of audiovisual activity in Mozambique, Angola, Guinea-Bissau and Cape Verde from its beginnings, in which cinema served first and foremost the nation-building purposes of the new states, to its search for cinematic formulae more interested in exploring the aesthetic dimension of art. Looking back in time over 40 years of Luso-African cinema, Ferreira argues that, although wa Thiong'o's decolonization of the mind has been the political stimulus of these films, they scarcely go beyond the limits of what Jacques Rancière calls political efficacy as their explicit goal was to forge an imagined political community after independence. It is no coincidence, as the author stresses, that film productions more engaged in aesthetic efficacy (Rancière 2009) achieved only a small distribution, instead attracting interest in contemporary academic research.

Raquel Schefer's article deals with Ruy Guerra's Mueda, Memória e Massacre, one of the first films that evidenced the integration of the colonial past into the new national narratives in Mozambique. Although this film has received some attention from researchers in recent years, the fact that there are three versions of it is less well known. Starting from the premise that the changes to the original film were not accidental, but rather due to 
the demands of the FRELIMO's struggle for hegemony, the author engages in an archaeology of the film material, putting individual changes in context. Analysing the images that have gone missing in between the film's first and its official version, Schefer identifies the FRELIMO's political and cultural programme, revealing the contradictions between ideology and political praxis in the late 1970s.

Pedro Costa's cinematographic productions also take issue with widespread discourses on decolonization and its consequences in Portugal in a similar manner. Ana Vera addresses Costa's Fontainhas trilogy, which appeared at a time when Portuguese society seemed to have left behind its past of backwardness and dictatorship and was cherishing new hopes of economic development and European integration. The very fact that the African communities living in slums in the outskirts of Lisbon are addressed in the trilogy places Costa outside the mainstream, challenging the widespread European euphoria and pointing out the failure of Portugal's integration policies. Made up of Ossos ('Bones') (1997), No Quarto da Vanda ('In Vanda's room') (2000) and Juventude em Marcha (Colossal Youth) (2006), this trilogy explores the lives and narratives of Cape Verdean immigrants living in Lisbon. Vera focuses her analysis of Pedro Costa's trilogy on Fontainhas' inhabitants' inability to possess their territory as their existence is marked by a movement of perpetual deterritorialization.

Robert Stock's article deals with the most recent production in this issue. The article presents an analysis of the documentary film Dundo, Memória Colonial ('Dundo, colonial memory') (2009) by the Portuguese journalist Diana Andringa. The article addresses the multifaceted way in which colonial Dundothe city where the Diamond Company of Angola, Diamang, had its administrative headquarters - is remembered in Portugal by former settlers and in Angola by former African workers, as presented by the film and even by the film director herself, who spent her childhood in Dundo. As Stock shows in his analysis, Dundo, Memória Colonial offers neither nostalgic nor anti-colonialist master narratives. Adopting the personal gaze of the witnesses, the film does not censure nostalgic and critical ways of remembering the past, instead presenting the memory of the colonial past as multi-layered and ambivalent because - irrespective of specific historical politics of history - memory is first and foremost connected to lived experience.

Despite reflecting the kaleidoscopic diversity of decolonization narratives, the films in this issue's case studies all converge in exploring cinema's potential to challenge mainstream narratives and to negotiate more critical approaches to the past. This is particularly true for recent productions that look at the past with distance and add new perspectives to established narratives and images. But also productions that emerged during the nation-building period of the new independent African states shortly after the end of Portuguese colonial rule had the power to demystify the decolonization and the postcolonial national narratives. These productions contribute towards decolonizing the mind, to use Ngũgĩ wa Thiong'o's term.

\section{REFERENCES}

Andrade-Watkins, Claire (1995), 'Portuguese African cinema: Historical and contemporary perspectives 1969 to 1993', Research in African Literatures, 26:3, pp. 134-50.

Arenas, Fernando (2011), Lusophone Africa: Beyond Independence, Minneapolis, MN: University of Minnesota Press. 
2015), 'Migrations and the rise of African Lisbon: Time-space of Portuguese (post)coloniality', Postcolonial Studies, 18:4, pp. 353-66.

Bickford-Smith, Vivian and Mendelsohn, Richard (eds) (2007), Black and White in Colour: African History on Screen, Oxford: Currey, Oxford University Press and Double Storey.

Buettner, Elizabeth (2016), Europe after Empire: Decolonization, Society, and Culture, Cambridge: University Press.

Cahen, Michel (2012), 'Anticolonialism and nationalism: Deconstructing synonymy, investigating historical processes', in Eric Morier-Genoud (ed.), Sure Road? Nationalisms in Angola, Guinea-Bissau and Mozambique, Leiden and Boston: Brill, pp. 1-30.

Chabal, Patrick (ed.) (2002), 'Lusophone Africa in historical and comparative perspective', in P. Chabal, A History of Postcolonial Lusophone Africa, London: Hurst, pp. 3-136.

Cham, Mbye B. (2004), 'Film and history in Africa: A critical survey of current trends and tendencies', in Françoise Pfaff (ed.), Focus on African Films, Bloomington: Indiana University Press, pp. 48-68.

Coelho, João Paulo Borges (2013), 'Politics and contemporary history in Mozambique: A set of epistemological notes', Kronos, 39:1, pp. 20-31.

Convents, Guido (2011), Os moçambicanos perante o cinema e o audiovisual: Uma história político-cultural do Moçambique colonial até à República de Moçambique (1896-2010), Maputo: Edições Dockanema, Afrika Film Festival.

Dinerman, Alice (2006), Revolution, Counter-revolution and Revisionism in Postcolonial Africa: The Case of Mozambique, 1975-1994, London and New York: Routledge.

Eshun, Kodwo and Gray, Ros (2011), 'The militant image: A Ciné-geography', Third Text, 25:1, pp. 1-12.

Fairfax, Daniel (2010), 'Birth (of the image) of a nation: Jean-Luc Godard in Mozambique', Acta Universitatis Sapientiae: Film and Media Studies, 3, pp. 55-67.

Fendler, Ute (2014), 'Cinema in Mozambique: New tendencies in a complex mediascape', Critical Interventions, 8:2, pp. 246-60.

Ferreira, Carolin Overhoff (2012), Identity and Difference: Postcoloniality and Transnationality in Lusophone Films, Münster: Lit.

Gray, Ros (2012), 'Cinema on the cultural front: Film-making and the Mozambican revolution', Journal of African Cinemas, 3:2, pp. 139-60.

Guerra, Ruy (1979/1980), Memória e Massacre ('Mueda, memory and massacre'), Mozambique: Instituto Nacional de Cinema.

Huyssen, Andreas (2003), Present Pasts: Urban Palimpsests and the Politics of Memory, Stanford, CA: Stanford University Press.

Israel, Paolo (2013), 'A loosening grip: The liberation script in Mozambican history', Kronos, 39:1, pp. 10-19.

Loff, Manuel (2010),'Coming to terms with the dictatorial past in Portugal after 1974: Silence, remembrance and ambiguity', in Stefan Troebst (ed.), Postdiktatorische Geschichtskulturen im Süden und Osten Europas: Bestandsaufnahme und Forschungsperspektiven, Göttingen: Wallstein, pp. 55-121.

Lubkemann, Stephen C. (2005), 'Unsettling the metropole: Race and settler reincorporation in postcolonial Portugal', in Caroline Elkins and Susan Pedersen (eds), Settler Colonialism in the Twentieth Century: Projects, Practices, Legacies, New York and London: Routledge, pp. 257-70. 
Medeiros, Paulo de (2000), 'Hauntings: Memory, fiction and the Portuguese colonial wars', in Timothy G. Ashplant (ed.), The Politics of War Memory and Commemoration, London: Routledge, pp. 201-21.

Melber, Henning (2009), 'Southern African liberation movements as governments and the limits to liberation', Review of African Political Economy, $36: 121$, pp. $451-59$.

Meleiro, Alessandra (2012), 'Luso-African cinema: Nation and cinema', Journal of African Cinemas, 3:2, pp. 135-38.

Minter, William, Hovey, Gail and Cobb, Charles Jr (eds) (2008), No Easy Victories: African Liberation and American Activists over a Half-Century, 1950-2000, Trenton, NJ: Africa World Press.

Pawson, Lara (2014), In the Name of the People: Angola's Forgotten Massacre, London: I.B. Tauris.

Pearce, Justin (2015), 'Contesting the past in Angolan politics', Journal of Southern African Studies, 41:1, pp. 103-19.

Peralta, Elsa, Góis, Bruno and Oliveira, Joana (eds) (2017), Retornar: Traços de memória do fim do império, Lisbon: Edições 70.

Piçarra, Maria do Carmo and António, Jorge (eds) (2013a), Angola: O nascimento de uma nação, Vol I: O cinema do império, Lisbon: Guerra \& Paz.

- (2013b), Angola: O nascimento de uma nação, Vol II: O cinema da libertação, Lisbon: Guerra \& Paz.

_ (2015), Angola: O nascimento de uma nação, Vol III: O cinema da independência, Lisbon: Guerra \& Paz.

Piçarra, Maria do Carmo, Cabecinhas, Rosa and Castro, Teresa (eds) (2016), 'Colonial imaginaries: Propaganda, militancy and "Resistance"', Comunicação e Sociedade, 29, pp. 17-23.

Pinheiro, Teresa (2015), 'O retorno dos retornados. A construção de memória do passado recente na série televisiva Depois do Adeus', in Elias J. Torres, Raquel BelloVázquez, Roberto Samartim and Manuel Brito-Semedo (eds), Estudos da AIL em Literatura, História e Cultura Portuguesas, Santiago de Compostela and Coimbra: Associação Internacional de Lusitanistas, pp. 279-90.

Rancière, Jacques (2009), The Emancipated Spectator, London and New York: Verso.

Ribeiro, Margarida Calafate, Vecchi, Roberto und Ribeiro, António Sousa (2012), 'The children of the colonial war: Post-memory and representations', in Isabel Capeloa Gil and Adriana Martins (eds), Plots of War: Modern Narratives of Conflict, Berlin and New York: De Gruyter, pp. 11-23.

Rosenstone, Robert A. (1998), Visions of the Past: The Challenge of Film to our Idea of History, Boston: Harvard University Press.

Seibert, Gerhard (2003), 'The vagaries of violence and power in post-colonial Mozambique', in Jon Abbink and Mirjam de Bruijn (eds), Rethinking Resistance, Leiden: Brill, pp. 253-76.

Stock, Robert (2014), 'Archival images and audiovisual testimony: Negotiating the end of empire in the documentary films Guerra Colonial: Historias de Campanha em Moçambique (1998) and Natal 71 (1999)', International Journal of Iberian Studies, 27:2-3, pp. 183-201.

Thackway, Melissa (2003), Africa Shoots Back: Alternative Perspectives in Sub-Saharan Francophone African Film, Bloomington: Indiana University Press.

Vieira, Patrícia (2015), 'Imperial remains: Post-colonialism in Portuguese literature and cinema', Portuguese Journal of Social Science, 14:3, pp. 275-86. 


\section{CONTRIBUTOR DETAILS}

Teresa Pinheiro has been a professor for Iberian Studies at the Institute for European Studies, Chemnitz University of Technology. She received her Ph.D. in Cultural Anthropology at the University of Paderborn in 2002. Within Iberian Studies her research fields are emigration, representations of collective identity and politics of memory. Recent publications: 'Les arpenteurs du monde' in Thomas Sarrier and Étienne François (eds), Europa (Paris: Les Arènes, 2017: 52-60); 'Memoria de la República en las transiciones democráticas ibéricas' in: Pasajes (48, 2015: 49-64); 'O retorno dos retornados' in: Elias J. Torres et al., Estudos da AIL (Santiago de Compostela: AIL, 2015: 279-90); Mass Media and the Configuration of Memory in Contemporary Spain and Portugal (with Esther Gimeno Ugalde) - special issue of the International Journal of Iberian Studies (27:2\&3, 2014).

Contact: Institut für Europäische Studien, Technische Universität Chemnitz, 09107 Chemnitz, Germany.

E-mail: Teresa.pinheiro@phil.tu-chemnitz.de

(D) https://orcid.org/0000-0003-2887-0449

Robert Stock coordinates the DFG-research unit 'Participation and Media. Between Demand and Entitlement' at the University of Konstanz. He has a Ph.D. in Cultural Studies (2017) and holds a Master Degree in European Ethnography from the Humboldt-University of Berlin (2009). In his dissertation project at the International Graduate Centre for the Study of Culture (Gießen) he analysed postcolonial memory politics in documentary films from Mozambique and Portugal. His main research interests are cultural practices of hearing and seeing, digital media and dis/ability, ambivalences of audiovisual testimony and postcolonial memory politics. Recent publications: (with Mathias Deneke, Anne Ganzert and Isabell Otto) (2016) ReClaiming Participation. Technology - Mediation - Collectivity. Bielefeld: transcript; (2014) 'Archival images and audiovisual testimony: Negotiating the end of empire in the documentary films Guerra Colonial. Histórias de campanhas em Moçambique (1998) and Natal 71 (1999)' in: International Journal for Iberian Studies 27:2\&3, pp. 183-201; (2012) 'Apologising for colonial violence: The documentary film Regresso a Wiriyamu, transitional justice, and Portuguese-Mozambican decolonisation' in: Reconciliation, Civil Society, and the Politics of Memory: Transnational Initiatives in the 20th and 21st Century, ed. by Birgit Schwelling. Bielefeld: transcript, pp. 239-76.

Contact: Research Unit 'Media and Participation', Department of Literature, Art and Media, Box 157, 78457 Konstanz, Germany.

E-mail: robert.stock@uni-konstanz.de

(D) https://orcid.org/0000-0002-2256-0928 